J. Amer. Soc. Hort. Sci. 118(1):119-129. 1993.

\title{
Genetic Diversity of Red Raspberry Varieties throughout the-World
}

\author{
Adam Dale \\ Horticultural Research Institute of Ontario, Box 587, Simcoe, Ont. N3Y 4N5, Canada \\ Patrick P. Moore \\ Puyallup Research and Extension Center, Washington State University, Puyallup, WA 98371
}

Ronald J. McNicol

Scottish Crop Research Institute, Invergowrie, Dundee DD2 5DA, Scotland

Thomas M. Sjulin

Driscoll Strawberry Associates, 404 San Juan Road, Watsonville, CA 95076

Leonid A. Burmistrov

Plant Introduction Department, The NI Vavilov, All-Union Scientific Research Institute of Plant

Industry, 44 Herzen Street, St. Petersburg 190000, Russia

Additional index words. Rubus idaeus, fruit breeding, inbreeding, pedigree analysis

\begin{abstract}
Pedigrees of 137 red raspberry (Rubus idaeus L.) varieties released throughout the world since 1960 were used to calculate: 1) the genetic contribution of founding clones to these varieties; 2) genetic relatedness among them; and 3) their inbreeding coefficients. Fifty founding clones contributed to the pedigrees of these varieties with a mean genetic contribution ranging from $<0.1 \%$ to $21 \%$. Varieties were clustered according to the genetic contribution into groups strongly related to geographical origin. Varieties developed in the former USSR and derived from 'Novost Kuzmina' formed a distinct cluster. The remaining varieties were clustered in groups based mainly on whether they were of North American or European origin. Varieties were clustered also on the basis of Wright's coefficient of relationship-a measure of genetic relatedness. Cluster groups were related to their geographical origin and the varieties within the groups could be traced to similar intermediate parents. Inbreeding coefficients ranged from 0.0 to 0.625 and were related, in part, to the numbers of generations of controlled hybridization from common ancestors. The British group, with the largest number of generations of breeding, had a low mean inbreeding coefficient, indicating that inbreeding can be minimized with attention to the mating system. Strategies are suggested for maintaining and increasing the genetic diversity in the world's red raspberry breeding populations.
\end{abstract}

The red raspberry has been cultivated since before the fourth century. Since then, the plant has been genetically improved, first by the development of local varieties, and since about 1800 , by deliberate hybridization (Jennings, 1988). To date, there have been three cycles of breeding: 1) many varieties were selected within Rubus idaeus subsp. idaeus and subsp. strigosus Michx. in the late 19th and early 20th centuries either from chance discoveries or from families of open-pollinated seedlings (Hedrick, 1925; Jennings, 1988); 2) some of these were used to produce idaeus $\times$ strigosus hybrid varieties; and 3 ) some of these hybrid varieties and some of the earlier chance discoveries were used to produce modern varieties (Jennings, 1988).

The result of this breeding strategy has been to produce varieties derived from very few parents, in particular 'Lloyd George'. Oydvin (1970) calculated that $69 \%$ of the varieties released between 1930 and 1970 were derived at least partially from 'Lloyd George'. Other varieties that have been important are 'Preussen' in Europe, 'Newman', 'Latham', 'Cuthbert', and 'Newburgh' in North America and 'Novost Kuzmina' in the former USSR (Daubeny, 1982; Jennings, 1988; Jennings et al., 1991; Oydvin, 1970).

The red raspberry was originally self-incompatible (Keep, 1968), but exploitation of a natural mutation at the incompatibility locus has enabled all modern varieties to be self-compat-

Received for publication 21 Jan. 1992. Accepted for publication 27 Apr. 1992 We thank C. Fear and V.H. Knight for contributions of unpublished pedigrees. The cost of publishing this paper was defrayed in part by the payment of page charges. Under postal regulations, this paper therefore must be hereby marked advertisement solely to indicate this fact. ible. This self-compatibility, however, encourages inbreeding, with losses in vigor, yield, and fruit size (Fejer and Spangelo, 1974).

Pedigree analysis has been used recently in other fruit crops to estimate the levels of inbreeding and genetic diversity of breeding populations (Hancock and Siefker, 1982; Lyrene, 1981; Scorza et al., 1985; Sjulin and Dale, 1987).

The purpose of this study was to use published red raspberry pedigrees to a) estimate the genetic diversity of the world raspberry varieties released since 1960 , and b) use these results to suggest ways that the genetic diversity can be both maintained and increased. The pedigrees were used to calculate: a) the genetic contribution of older Rubus clones to the world's red raspberry varieties released since $1960, b)$ the degree of genetic relatedness among these varieties, and c) the level of inbreeding in these varieties.

\section{Materials and Methods}

The 137 raspberry varieties included in this study are named varieties of known parentage released throughout the world since 1960. Their pedigrees were obtained from various sources, including Brooks and Olmo (1971, 1972a, 1972b, 1973, 1974, 1975, 1978, 1982, 1983, 1984), Jennings (1988), published variety descriptions, and personal communications from raspberry breeders. Four varieties of unknown origin, 'Fallbrook', 'Rannyaya Sladkaya', 'Sweetbriar', 'Sparkling Gem' ( Rubus

Abbreviations: CR, coefficient of relationship; GC, genetic contributions. 
phoenicolasius L.), and the Arctic raspberries were not included.

Calculations of the genetic contribution, the coefficient of relationship and inbreeding coefficients and cluster analyses, were based on the methods of Sjulin and Dale (1987).

Genetic contribution. The genetic contribution (GC) of a clone to a variety was calculated as: $\mathrm{GC}=\mathrm{E}(1 / 2)^{\mathrm{N}}{ }_{1 \ldots \mathrm{x}}$ where $\mathrm{n}$ is the number of generations in a pedigree pathway between the clone and the variety, and $\mathrm{x}$ is the total number of pathways between the clone and the variety. Three assumptions were made in GC calculations: 1) genotypes selected from open-pollinated populations were self-pollinated by the female parent; 2) where 'Loganberry' was found in a pedigree, the $F_{1}$ with red raspberry was considered to be diploid, with GC 50\% 'Auginbaugh' blackberry, 25\% 'Red Antwerp', and 25\% red raspberry genotype; and 3) where Rubus chamaemorus L. was used, the $F_{1}$ was considered to be diploid with equal contributions from $R$. chamaemorus and the red raspberry. The first assumption may not always be correct, as 'Cuthbert' is thought to be a hybrid between 'Hudson River Antwerp' (Jennings, 1988) and $R$ idaeus subsp. stigosus, and Dale (unpublished data) has shown that up to $50 \%$ of selections from open-pollinated seed from small breeding plots of red raspberries can be hybrids. However, in the case of 'Cuthbert', which accounts for most of the 'Hudson River Antwerp' accessions, this will have 'little effect on the analyses, as either the self or the hybrid will have a unique germplasm. Pedigree pathways ended when a clone of unknown or disputed origin was encountered and that clone was classified as a "founding clone." A BASIC program was used with an IBM PC-AT microcomputer (Sjulin and Dale, 1987) to determine the percentage of GC of each founding clone to a given variety.

Varieties were grouped according to their GC using Ward's method (Ward, 1963). The GC of 21 founding clones that were present in the pedigrees of seven or more varieties were used as input variables. The remaining 29 founding clones were present in the pedigrees of five or fewer varieties. All varieties with identical or reciprocal parentage were represented by one of them, Clusters were merged until the decrease in the coefficient of determination caused by joining the clusters (semipartial $R^{2}$ ) exceeded 0.02 .

Genetic relatedness. Genetic relatedness among varieties was estimated by coefficients of relationship (CR), which measure the probability that two individuals carry the same allele (Wright, 1922). CR were calculated from pedigrees as: $C R=2$ Fxy/d $(1+F x)(1+F y)$, where Fxy is the inbreeding coefficient of offspring from the hypothetical mating between varieties $\mathrm{x}$ and $\mathrm{y}$, and Fx and Fy are the inbreeding coefficients of varieties $\mathrm{x}$ and $\mathrm{y}$, respectively (Hartl, 1980). Intermediate parent clones, as well as founding clones, shared in common between two varieties contributed to the $\mathrm{CR}$.

The varieties were clustered by Ward's Method (Ward, 1963), and the CR were used as input variables. All varieties with identical or reciprocal parentage were represented by one of them, and CR were calculated for all possible combinations of hypothetical matings among these 124 varieties. A CR of 1.0 was used for self-matings. Clusters were merged until the semipartial $R^{2}$ exceeded 0.02 .

Inbreeding. Inbreeding coefficients were calculated for each variety by Wright's Pedigree Method (Wright, 1922) SAS INBREED procedure (Barr, 1983). For the calculation of both the $\mathrm{CR}$ and inbreeding, genotypes selected from open-pollinated populations were considered to result from self-pollination, and all $\mathrm{F}_{1} \mathrm{~S}$ were considered to be diploid with equal contributions from each parent.

\section{Results and Discussion}

Genetic contribution. All 137 varieties of known parentage were derived from only 50 founding clones (Table 1). The mean $\mathrm{GC}$ of founding clones ranged from $<0.1 \%$ to $21 \%$. This range indicates that a restricted sample of the raspberry germplasm has been used for the world's red raspberry varieties. In comparison, the 134 North American strawberry ( Fragaria $\times$ ananassa Duch.) varieties released over a similar period had 53 founding clones (Sjulin and Dale, 1987), and the 47 genetically improved highbush blueberry (Vaccinium corymbosum L.) varieties released up to 1982 originated from 17 founding clones (Hancock and Siefker, 1982).

Fourteen of the 15 founding clones with a mean GC > 1\% were introduced in the 19th or early 20th centuries. All are red raspberries of either subsp. idaeus or subsp. strigosus. The 15th founding clone, 'Creston', is of unknown origin but was found in a commercial field in British Columbia. Fejer (1977) believed it to be at least $50 \%$ 'Lloyd George'.

Four founding clones occur in more than 90 pedigrees. These are 'Lloyd George', 'Hudson River Antwerp', 'English Globe', and 'Highland Hardy'. The latter three, however, are only found in two intermediate parents, 'Cuthbert' and 'Marlboro'; both are derived from 'Hudson River Antwerp', with 'Marlboro' also derived from 'English Globe' and 'Highland Hardy'.

'Lloyd George', which has a mean GC of $21 \%$, is present in $79 \%$ of the varieties. This is more than the $69 \%$ that caused concern to Oydvin (1970). Indeed, if the Russian varieties are removed from the calculation, 'Lloyd George' is present in $87 \%$ of all European and American red raspberries.

Of the 21 founding clones occurring seven or more times in the pedigrees, the six with a mean $\mathrm{GC}<1 \%$ contain varieties of three species: a) $R$. ursinus Cham. et Schlecht 'Auginbaugh' is one parent of 'Loganberry', b) R. chameamorus L., and c) $R$. occidentalis L. 'Cumberland'. Despite there being many named black raspberry varieties, 'Cumberland' is the only one that appears in the red raspberry pedigrees.

Of the remaining 25 founding clones, six species have been introduced for specific purposes. Rubus parvifolius Nutt. and $R$. kunzeanus Hemsl. have been introduced for heat tolerance (Overcash, 1973), R. cockburneanus Hemsl. for increased number of flowers (Knight et al., 1989), and $R$. odoratus L. for disease and pest resistance (Keep, 1989).

Cluster analysis, based on GC of the founding clones, sorted the varieties into 13 groups that were strongly related to geographic origin. All groups seem to be clustered according to a high GC of one or two founding clones. The greatest separation was between a small group of Russian varieties (cluster group 1) and the remainder of the varieties (Table 2; Fig. 1). All varieties in cluster group 1 have a high GC from 'Novost Kuzmina'.

The remaining 12 cluster groups were separated mainly on geographic origin, although the Russian varieties were included in several of the European groups.

Cluster group 2, the southern and central U.S. group, is characterized by approximately equal contributions from 'Ranere', 'Newman', and 'Lloyd George'. All the varieties in this group except one have a GC from 'Ranere' >13\%. The GC from 'Ranere' came mostly through the intermediate parents 'Sunrise' and 'September', and those of 'Newman' through 'Newburgh', 'Taylor', and 'Marcy'. 'Malling Autumn Bliss' from the United 
Table 1. Origin, frequency of occurrence, and GC of founding clones to the 137 world raspberry (Rubus) varieties.

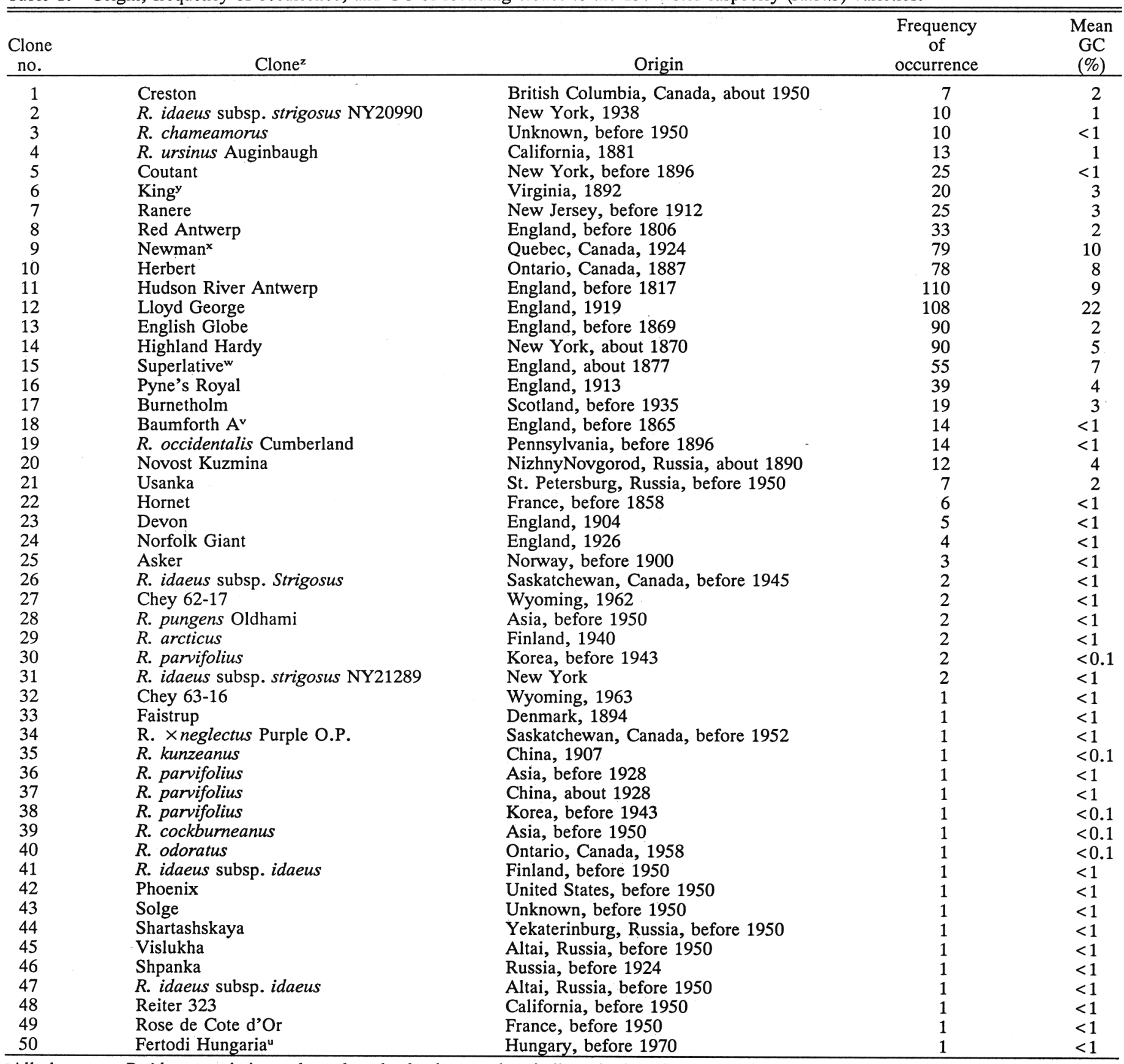

${ }^{2}$ All clones are $R$. idaeus varieties and numbered selections, unless indicated otherwise.

y'Thompson' open-pollinated.

'Open-pollinated seedling of one of 'Cuthbert', 'Herbert', 'Kıng', or 'Loudon'.

"Synonymous with 'Northumberland Filbasket'.

'Derived from 'Northumberland Filbasket'.

['Loganberry' $\times$ ( $R$. caesius $\times$ 'Lloyd George') doubled] selfed (L. Kollanyi, personal communication).

Kingdom is included in this group, as its fall-bearing parent NY783 has 'September' contributing to three of its grandparents.

The largest and most geographically diverse group is cluster group 3. This contains North American varieties and their derivatives. It contains a high percentage GC of 'Newman' and
'Lloyd George' and either NY20990 or 'Herbert'. It contains all the North American fall-bearing varieties, except 'Heritage', and varieties from northern Europe, the former USSR, and Mexico.

All the American fall-bearing raspberries, except 'Joe Mello', trace their fall-bearing habits back to 'Heritage' or 'August Red' 


\begin{tabular}{|c|c|c|c|c|c|c|c|c|c|c|c|c|c|c|c|c|c|c|c|c|c|c|}
\hline \multirow[b]{3}{*}{ Variety } & \multicolumn{21}{|c|}{ GC $(\%)$ of founding clones $y$} & \multirow[b]{3}{*}{ Other } \\
\hline & \multicolumn{21}{|c|}{ Clone } & \\
\hline & 1 & 2 & 3 & 4 & 5 & 6 & 7 & 8 & 9 & 10 & 11 & 12 & 13 & 14 & 15 & 16 & 17 & 18 & 19 & 20 & 21 & \\
\hline \multicolumn{23}{|l|}{ Cluster group 1 (Russian) } \\
\hline Prigorodnaya ${ }^{w}$ & -- & -- & $\cdots$ & $\cdots$ & $\cdots$ & $\cdots$ & $\cdots$ & -- & $\cdots$ & $\cdots$ & 25 & -- & -- & -- & -- & -- & $\cdots$ & -- & $\cdots$ & 75 & -- & \\
\hline Tenkovskaya Rannyaya & --- & --- & $-\cdots$ & -.. & -.- & --- & --- & 50 & --- & --- & --- & --- & --- & --- & --- & --- & --- & --- & --- & 50 & --- & \\
\hline Alenkaya & --- & -- & -- & $-\cdots$ & -- & --- & $-\cdots$ & -- & --- & --- & --- & --- & --- & --- & --. & $\cdots$ & $\cdots$ & --- & -- & 50 & 50 & \\
\hline Rannii Surpriz & -- & --- & --- & --- & --- & --- & --- & --- & --- & --- & --- & 25 & --- & --- & --- & $--\cdot$ & --- & --- & -- & 50 & 25 & \\
\hline Samarskaya Ploynaya & --- & --- & --- & --- & $-\cdots$ & --- & --- & --- & --- & --- & 6 & --- & 6 & 13 & 25 & --- & --- & --- & -- & 50 & --- & \\
\hline Odarka & $\cdots$ & --- & -- & 13 & --- & --- & --- & 6 & --- & --- & 14 & 13 & 2 & 3 & $\cdots$ & $\cdots$ & $\cdots$ & $-\cdots$ & -- & 50 & --- & \\
\hline Meteor $^{\mathrm{v}}$ & --- & --- & --- & --- & --- & --- & --- & --- & --- & --- & 3 & 25 & 3 & 6 & 13 & --- & --- & --- & --- & 50 & --- & \\
\hline Alyi parus & --- & --- & -- & --- & --- & --- & --- & --- & --- & --- & 2 & 13 & 2 & 3 & 6 & --- & $-\cdots$ & --- & --- & 25 & -- & $43(50)$ \\
\hline Obilnaya & --- & -- &.-- & $-\cdots$ & --- & --- & --- & --- & --- & --- & 50 & --- & --- & --- & --- & --- & --- & --- & --- & 50 & --- & \\
\hline $\begin{array}{l}\text { Cluster group } 2 \text { (southern } \\
\text { central United States) }\end{array}$ & & & & & & & & & & & & & & & & & & & & & & \\
\hline Lake Geneva & -- & --- & --- & --- & --- & 25 & 50 & 13 & --- & --- & 13 & --- & --- & $-\cdots$ & $\cdots$ & $-\cdots$ & $--\cdot$ & $\cdots$ & $\cdots$ & $\cdots$ & $\cdots$ & \\
\hline Liberty & --- & -- & -- & -.- & -- & 13 & 25 & 6 & 25 & 25 & 6 & --- & -- & --- & --- & --- & --- & --- & --- & --- & --- & \\
\hline Southland & --- & --- & -- & --- & --- & 9 & 19 & 5 & 19 & 19 & 5 & 13 & -.- & --. & --. & --. & --- & -.- & --- & --. & -- & $30(13)$ \\
\hline Citadel & -.- & --- & --- & --- & -- & 6 & 13 & 3 & 25 & 19 & 3 & 19 & --- & --- & --- & --- & --- & --- & --- & --- & --- & $38(13)$ \\
\hline Sentry & --- & --- & --- & --- & --- & 13 & 25 & 6 & 25 & --- & 6 & 25 & --- & --- & --- & --- & --- & --- & --- & --- & -- & \\
\hline Sentinel & --- & -.. &.-- & -- & -- & 13 & 25 & 6 & 13 & 13 & 6 & 25 & -- & --- & --- & --- & --- & --- & --- & -- & --- & \\
\hline Reveille & --- & --- & --- & --- & 3 & 6 & 37 & 3 & 13 & 6 & 4 & 25 & 1 & 2 & --- & --- & -- & --. & --- & --- & -- & \\
\hline Scepter & -- & --- & $\cdots$ & $\cdots$ & -- & -- & 25 & --- & 37 & --. & --. & 37 & --- & --- & --- & --- & --- & --- & --- & --- & --- & \\
\hline Cherokee $^{u}$ & --- & --- & --- & --- & --- & --- & 25 & --- & 25 & 13 & --- & 25 & --. & --- & -.- & --- & --- & --- & --- & --- & ---2 & $22(13)$ \\
\hline Malling Autumn Bliss & --- & $\cdots$ &.-- & --- & 1 & --- & 16 & --- & 15 & 2 & 1 & 22 & 1 & 2 & 3 & 2 & 6 & 7 & 2 & -- & --2 & $24(3), 29(13), 31(6)$ \\
\hline Cluster group 3 (North & & & & & & & & & & & & & & & & & & & & & & \\
\hline American and derivative & & & & & & & & & & & & & & & & & & & & & & \\
\hline Nova & --- & --- & --- & --- & 3 & 17 & 9 & 9 & 9 & 16 & 9 & 19 & 1 & 2 & --. & -- & --- & --- & -- & --- & --- & $30(6)$ \\
\hline Joe Mello & -- & --- & -- & --- & --- & 3 & --- & 2 & 13 & 13 & 8 & 13 & --- & --- & --- & --- & --- & --- & --- & -- & --- & $48(50)$ \\
\hline Nordic & --- & 13 & 6 & --- & 4 & 13 & --- & 6 & 13 & 8 & 7 & 28 & 1 & 2 & --- & --- & --- & --- & --- & --- & --- & \\
\hline Trailblazer & --- & 13 & 6 & -- & 1 & $\ldots$ & --- & -- & 13 & 2 & 1 & 16 & 1 & 1 & --- & --- & --- & --- & -- &.-- & --- & $32(50)$ \\
\hline Pathfinder & --- & 13 & 6 & --- & 1 & --- & --- & --- & 13 & 2 & 1 & 16 & 1 & 1 & --- & --- & --- & --- & --- & --- & --- & $27(50)$ \\
\hline Fallred ${ }^{t}$ & --- & 25 & 13 & --- & 2 & --- & -- & --- & 25 & 3 & 1 & 31 & 1 & 1 & --- & --- & --- & --- & --- & --- & --- & \\
\hline Prestige & --- & --- & --- & --- & --- & --- & --- & --- & 25 & --- & --- & 25 & --- & --- & --- & --- & --- & --- & --- & --- & --- & $28(50)$ \\
\hline Fallgold & --- & 13 & 6 & -.- & 1 & --- & --- & --- & 25 & 2 & 1 & 28 & 1 & 1 & -.- & --. & --- & --- & --- & --. & --- & $28(25)$ \\
\hline Redwing & --- & 13 & 6 & --- & 1 & --- & --- & --- & 28 & 5 & 13 & 34 & 1 & 1 & --- & --- & --- & --- & --- & --- & --- & \\
\hline Itasca & -.. & --- & --- & -- & -- & --- & -- & --- & 50 & 50 & --- & --- & --- & --- & --- & --- & --- & --- & -- & -- & --- & \\
\hline Royalty & --- & --- & --- & --- & 3 & --- & --- & --- & 25 & 31 & 1 & 13 & 1 & 2 & --- & --- & --- & --- & 25 & --- & --- & \\
\hline Festival & --- & --- & --- & -.- & -.. & --- & --- & --- & 50 & 25 & -.- & 25 & -.. & -.- & --. & --- & --- & --- & -- & -- & --- & \\
\hline Spolokh & --- & --- & --- & --- & -- & --- & --- & --- & 37 & 37 & --- & 13 & --- & --- & --- & 13 & --- & --- & --- & --- & --- & \\
\hline Titan & --- & --- &.-- & -.. &.- & -- & 13 & --. & 31 & 25 & $-\cdots$ & 19 & --- & --- & --- & --- & --- & --- & -- & --- & -- & $22(13)$ \\
\hline Dalnaya & --- & --- & --- & 6 & --- & --- & 3 & 3 & 37 & 25 & 8 & 13 & 2 & 3 & --- & --- & --- & --- & --- & --- & --- & \\
\hline Jochems Roem & --- & --- & --- & --- & --- & --- & -- & -- & 25 & 25 & -- & 25 &.-- & $-\cdots$ & --- & 25 & --- & --- & --- & --- & --- & \\
\hline Anita & --- & --- & --- & --- & --- & --- & --- & --- & 25 & 25 & --- & 25 & --- & --- & --- & 25 & --- & --- & --- & --- & --- & \\
\hline Nootka & --- & -- & --- & 6 & --- & --- & 3 & 3 & 25 & 13 & 8 & 37 & 2 & 3 & --- & --- & --- & --- & --- & --- & --- & \\
\hline Summit & -.. & 6 & 3 & -- & 1 & --- & 6 & --- & 31 & 16 & 6 & 30 & 1 & 1 & --- & --- & -- & --- & -- & --- & --- & \\
\hline Watson (Ruby) & --- & --- & --- & --- & --- & --- & 6 & --- & 31 & 16 & 13 & 28 & --- & -- & --- & -- & --- & --- & --- & --- & --- & $22(6)$ \\
\hline Himbo Queen & ... & -.- & -.. &.- & --- & -.- & --- & --. & 25 & 13 & 13 & 37 & $\ldots$ & -.- & -.- & 13 & --. & -.- & -.- & -.. & --- & \\
\hline Kirzhatch & --- & --- & --- & 6 & --- & --- & 3 & 3 & 25 & 13 & 8 & 25 & 2 & 3 & --- & 13 & --- & -- & --- & --- & --- & \\
\hline Amity & --- & 6 & 3 & --- & 1 & -- & -- & --- & 22 & 10 & 10 & 30 & 1 & 2 & 3 & 4 & --- & 7 & 2 & --- & --- & \\
\hline Tulameen & --- & --- & --- & 3 & --- & --- & 2 & 2 & 16 & 9 & 5 & 31 & 2 & 4 & 5 & 3 & 9 & 2 & 2 & --- & --- & $23(6)$ \\
\hline Shopska Alena & -.. & --- &.-- & --- & --- & --- & --- & --- & 25 & 25 & 3 & 25 & 3 & 6 & 13 & -- & --- & -.- & $-\ldots$ & -- & -.- & \\
\hline Ljulin & -- & --- & --- & --- & --- & --- & -- & 25 & 25 & 3 & 25 & 3 & 6 & 13 & --- & -- & -- & -- & --- & -- & & \\
\hline Esenna Pozlata & --- & --- & --- & -- & --- & --- & --- & -- & 25 & 25 & 3 & 25 & 3 & 6 & 13 & --- & --- & --- & --- & --- & -- & \\
\hline Chilcotin & -- & --- & --- & --- & --- & 6 & -- & 3 & 25 & 25 & 16 & 25 & --- & --- & --- & --- & --- & --- & -- & --- & --- & \\
\hline Hilton & --- & -- & --- & --- & -- & --- & -- & --- & 25 & 25 & -- & 25 & --- & --- & --- & --- & --- & --- & --- & --- & --- & $22(25)$ \\
\hline Vene & --- & --- & --- & --- & --- & --- & --- & --- & 25 & 25 & -- & 25 & --- & --- & --- & --- & --- & -- & -- & -- & --- & $25(25)$ \\
\hline Cluster group 4 (north Eur & & & & & & & & & & & & & & & & & & & & & & \\
\hline Norna $^{\mathrm{r}}$ & $\cdots$ & -- & -- & -- & -- & -- & -- & -- & -- & -- & 6 & 50 & 6 & 13 & 25 & --- & -- & -- & -- & --- & --- & \\
\hline Balder & --- & -- & --- & --- & --- & --- & --- & --- & -- & --- & 6 & 37 & 6 & 13 & 25 & 13 & --- & -- & --- & --- & --- & \\
\hline Gradina ${ }^{q}$ & --- & --- & --- & --- & --- & --- & --- & --- & 13 & 13 & 3 & 37 & 3 & 6 & 13 & 13 & --- & --- & --- & --- & --- & \\
\hline Spica & -.- & --- &.-- & -- & --- &.-- & -- &.-- & 13 & 13 & 3 & 37 & 3 & 6 & 13 & 13 & --. & --- & --- & -.. & -.. & \\
\hline Promiloy & --- & --- & --- & --- & --- & --- & -- & --- & 13 & 13 & 3 & 37 & 3 & 6 & 13 & 13 & --- & --- & --- & --- & --- & \\
\hline Sirius & -.- & -.- & --. & -- & --- & --- & $-\ldots$ & --. & 13 & 13 & 3 & 50 & 3 & 6 & 13 & --- & --. & --. & -.. & -.. & -.- & \\
\hline Zeva I & --- & --- & --- & --- & --- & --- & --- & --- & 13 & 13 & 3 & 50 & 3 & 6 & 13 & --- & --- & --- & --- & --- & --- & \\
\hline Gevalo $^{p}$ & -.- & -- & --- & 3 & -- & --- & --- & 13 & 19 & 4 & 37 & 4 & 8 & 13 & -- & --- & --. & -- & --- & --- & --- & \\
\hline Geloy & --- & --- & --- & --- & --- & 3 & --- & -- & --- & 13 & 19 & 4 & 37 & 4 & 8 & 13 & --- & --- & --- & --- & --- & \\
\hline
\end{tabular}







Table 2. Continued.

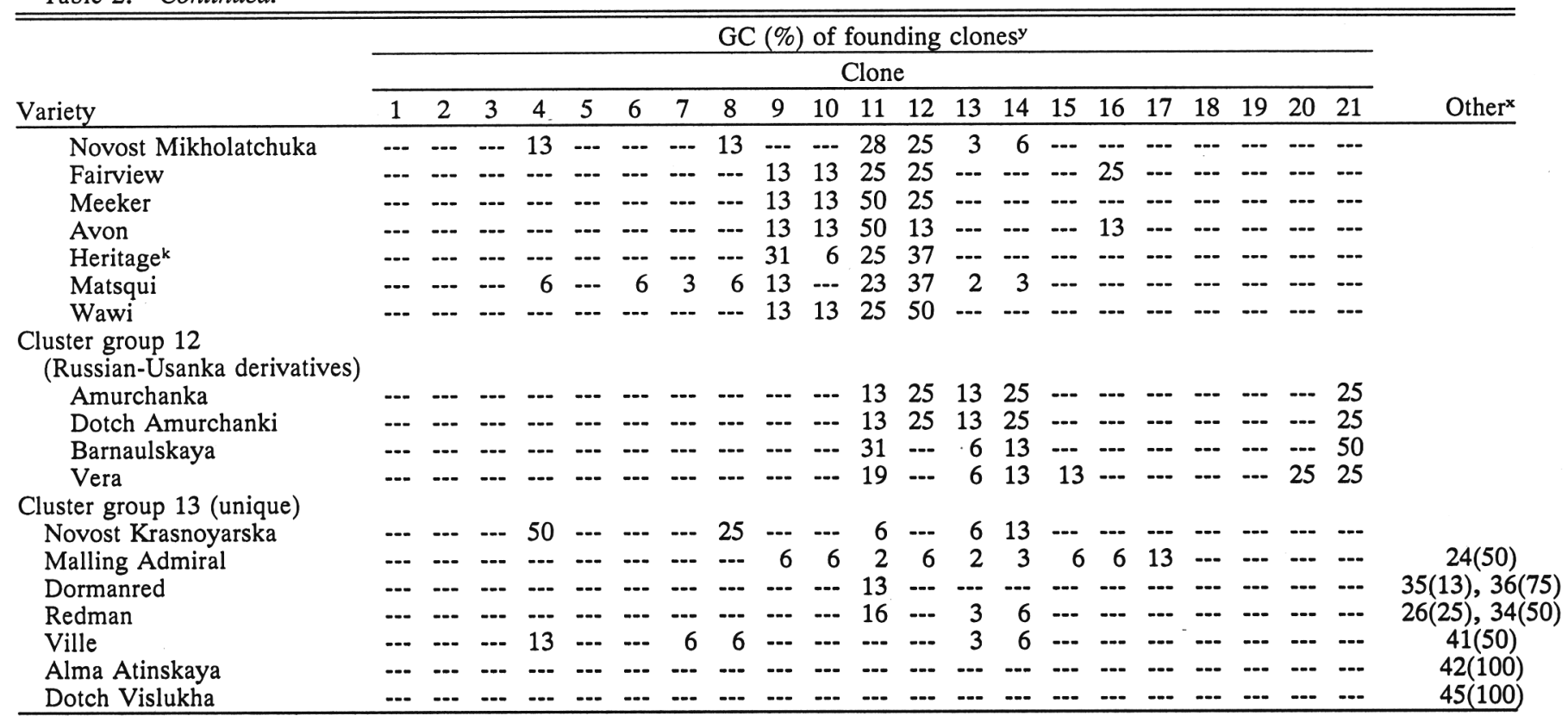

'Cluster analysis (Ward's hierarchical method) based on GC of founding clones nos. 1-21.

'See Table 1 for names of founding clones.

xPercent GC in parentheses; number preceding parentheses is founding clones no. (see Table 1).

"Sibling: 'Novokitayevskaya'.

vSibling: 'Bryanskaya'.

uSibling: 'Pocahontas'.

'Sibling: 'Augustred'.

sSibling: 'Gina'.

rSibling: 'Ralitsa'. 'Granat' added after analysis.

'Sibling: 'Krupna Dvoroda'.

PSibling: 'Trajilo'.

'Sibling: 'Synga'.

"Sibling: 'Ott's Pennridge'.

mSibling: 'Killarney'.

'Sibling: 'Skromnitsa'.

kSport: 'Kiwigold'.

and its sib 'NH56-1'. All three have 'Durham' as the fall-bearing ancestor. Both R. chameamorus L. and NY20990 are ancestors of 'August Red' and 'NH56-1'. The fall-bearing pedigree of 'Joe Mello' is unknown.

With the exception of 'Prestige', all the summer-bearing varieties in this group are closely related to 'Newburgh' ('Newman' $\times$ 'Herbert'). 'Itasca' is 'Newburgh' selfed; 'Spolokh', 'Dalanya', 'Shopska Elena', 'Ljulin', 'Chilcotin', 'Vene', and 'Hilton' all had 'Newburgh' as one parent. 'Festival' had 'Muskoka', a sib of 'Newburgh', as one parent. All the other summer-bearing varieties in this group, except 'Tulameen' and 'Nova', had 'Newburgh' as at least one grandparent, often with 'Malling Promise' and 'Malling Exploit' as the intermediate parent. In 'Tulameen', 'Newburgh' is found in the pedigrees of both 'Nootka' and 'Glen Prosen', and in 'Nova', 'Newburgh' is present in the pedigree of 'Southland'.

Cluster group 4, the north European group, includes the two North American varieties (Sensation) and (Perron's Red). This group is characterized by a high percent GC from 'Lloyd George'. Intermediate parents in this group are 'Preussen' and 'Newburgh'. 'Norna' and 'Ralitsa' are sibs from the cross 'Preussen' $\times$ 'Lloyd George'. Eight other varieties in this group have other varieties from this cross as one of their parents. 'Newburgh' enters the pedigrees mainly through 'Malling Exploit', 'Malling Promise', and 'Willamette'.

Cluster group 5 contains two 'Superlative' derivatives. 'Superlative' contributes at least $75 \%$ of the GC to both varieties.

In cluster group 6, the central European group, all varieties except 'Zeva II' and 'Podgorina' have either 'Preussen' or its sib ' $4 \mathrm{~A}$ ' as one parent. The two exceptions have 'Rote Wadenswil' ('Preussen' $\times$ 'Superlative') as one parent. Also, the five German varieties and 'Kaskad' have varieties from the cross 'Preussen' $x$ 'Lloyd George' as one grandparent. This gives the high percent contribution of 'Superlative' to this group.

Cluster group 7, the British group, contains all the British varieties except 'Malling Autumn Bliss' and 'Malling Admiral'. All have a complex pedigree that, in some cases, can be traced back 13 generations. All have seven founding clones ('Lloyd George', 'Burnetholm', 'Pyne's Royal', 'Superlative', 'Hudson River Antwerp', 'English Globe', and 'Highland Hardy') with high percent GC from 'Lloyd George' and 'Burnetholm'.

Cluster group 8, the Pacific Northwest group, contains six varieties that are closely related and are essentially hybrids between 'Creston' and British germplasm. 'Chilliwack', 'Centen- 


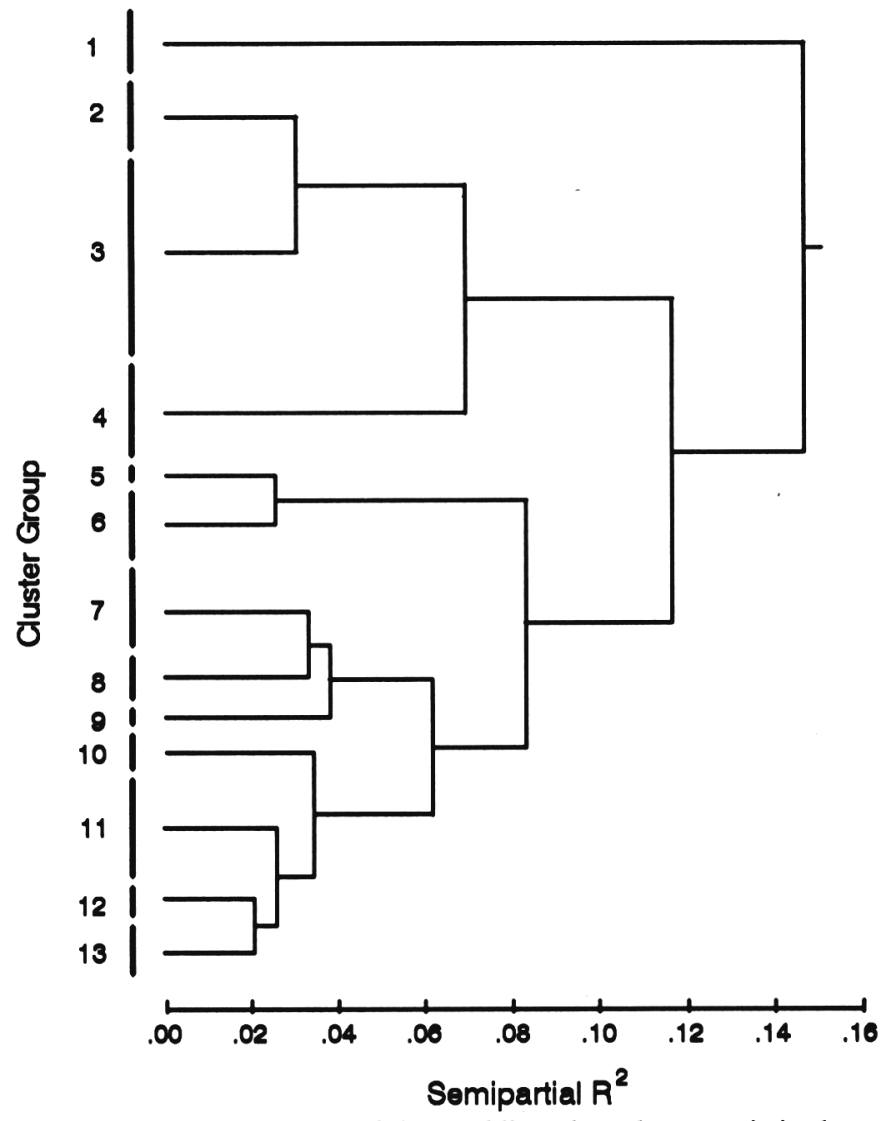

Fig. 1. Cluster dendogram of the world's red raspberry varieties based on GC of founding clones, using Ward's hierarchial method. Vertical bars indicate relative numbers of varieties in each group. Varieties composing cluster groups are listed in Table 2.

nial', and 'Comox' have 'Skeena' as one parent, and 'Algonquin' has 'Haida' as one parent. 'Skeena' and 'Haida' are hybrids of 'Creston' with British selections.

The two Danish varieties in cluster group 9 have 'Pyne's Royal' as at least one parent.

Cluster group 10, 'Latham' derivatives, contains five varieties. 'Earlibest' and 'Ott's Pennridge' are 'Latham' selfed, and 'Redbrook' is three-quarters derived from 'Chief', which is also 'Latham' selfed. 'Boyne' and 'Killarney' have 'Chief' as one parent.

Cluster group 11, the northern group of varieties from North America, the former USSR, France, and Hungary, contains varieties with a high GC from 'Lloyd George' and 'Hudson River Antwerp'. The 'Hudson River Antwerp' contribution is derived through the intermediate parent 'Cuthbert'. 'Viking' ('Cuthbert' $\times$ 'Marlboro') is either one parent or a grandparent of half the varieties in this group: 'Fertodi Zamatos', 'Frazer', 'Honeyqueen', 'Lazarevskaya', 'Matsqui', 'Skromnitsa', 'Sputnitsa', and 'Zorenka Altaya'. 'Washington', another offspring of 'Cuthbert', is one parent of 'Fairview', 'Matsqui', and 'Wawi'.

Cluster group 12 contains four Russian varieties related to 'Usanka' and 'Marlboro'.

Cluster group 13, the unique group, contains those varieties with at least half GC from rare or unique founding clones.

Genetic relatedness. The CR values for matings between individual varieties usually did not deviate markedly from the mean coefficient relationship for matings with or between their respective cluster groups (data not presented). Therefore, only the mean CR within or between cluster groups are presented (Table 3). The varieties included in each cluster group are listed in Table 4.

Cluster analysis based on CR (Table 4; Fig. 2) generally support relationships between varieties described by their GC (Table 2; Fig. 1). There are differences between the two cluster analyses because methodologies differ. When clusters are based on GC, the founding clones are the criteria used and intermediate parents are irrelevant. When clusters are based on CR, intermediate parents become more important.

Groups 1 and 2 are distinct groups with high CR within each group and low coefficients with other groups. Group 3 has low CR both within the group and with other groups. Groups 4-6 have high CR between these groups and with groups 9 and 10 . Groups 7-10 are less distinct and have high levels of relationship with each other.

Cluster group 1 is composed of varieties that originated in north-central North America. All of the varieties have a high percentage of 'Latham' or 'Chief' ('Latham' selfed).

Cluster group 2, the Russian group, is identical to the Russian group from the analysis of the GC, except for 'Odarka'. It is not closely related to any other group. All its varieties are closely related to 'Novost Kuzmina'.

Cluster group 3 is the unique group. Two varieties, 'Alma Atinskaya' and 'Dotch Visluka' had a CR of 0 with all varieties. Both are derived directly from clones of unknown ancestry. This group had low CR within the group and with all other groups.

Cluster group 4, 'Loganberry'-'Marlboro' derivatives, is composed of varieties with 'Loganberry' in their ancestry. These varieties were derived from 'Loganberry' through 'Ottawa' or 'Texas'. The other five varieties in this group have 'Marlboro' and/or 'Cuthbert' in their derivation.

Cluster group 5, the 'Preussen'-'Superlative' group, contains group 6 of the analysis of the $\mathrm{GC}$ with both varieties from group 5 plus 'Norna' and 'Balder' of group 4. Varieties in this group are related to 'Preussen' ('Superlative' $\times$ 'Marlboro') or 'Superlative'. This group has high CR with cluster group 10 .

Cluster group 6 contains all of the British varieties and some Pacific Northwest varieties derived from British material. All of the varieties have 'Burnetholm' in their ancestry and most also contain 'Cumberland'.

Cluster group 7, the North American fall-fruiting group, contains fall-fruiting varieties and some related summer-fruiting varieties. Nine of the 17 varieties in this group have $\mathrm{NH}-\mathrm{R} 7$ varieties in their pedigrees. The remaining eight varieties are included in this group because they share common ancestry with this group of nine. 'Fallgold' has NH-R7 as one parent and 'Taylor' $\times$ R. pungens oldhamii Mig. hybrid as the other parent. This is one of the parents of 'Prestige', and, as a result, 'Prestige' is included through its relationship to 'Fallgold'. 'Heritage', 'Scepter', and NH-R7 all have 'Durham' as a parent. 'Watson' (Ruby) has 'Heritage' as one parent. The remaining four varieties all have 50\% 'Lloyd George' or more in their pedigrees. Varieties in this group have high $\mathrm{CR}$ with groups 8-10.

Cluster group 8, the 'Newburgh'-'Sunrise' group, is composed primarily of varieties from the eastern United States. Fourteen of the 17 varieties in this group have at least $25 \%$ 'Newburgh' in their parentage. Four of these 14 also have at least 25\% 'Sunrise'. The three varieties that do not contain $25 \%$ 'Newburgh' ('Nova', 'Reveille', and 'Sentry') all have at least $25 \%$ 'Sunrise'. 'Festival' is 50\% 'Muskoka', a sib of 'Newburgh', and therefore is included in this group.

Cluster group 9, the 'Malling Exploit'-'Malling Promise' 
Table 3. Mean CR for matings of raspberry varieties within and between cluster groups. ${ }^{2}$

\begin{tabular}{|c|c|c|c|c|c|c|c|c|c|c|c|}
\hline \multicolumn{2}{|r|}{ Cluster group } & \multicolumn{10}{|c|}{ Cluster group no. } \\
\hline No. & Name & 1 & 2 & 3 & 4 & 5 & 6 & 7 & 8 & 9 & 10 \\
\hline 1 & Latham & 0.438 & - & & & & & & & & \\
\hline 2 & Novost Kuzmina & 0.039 & 0.270 & & & & & & & & \\
\hline 3 & Unique & 0.054 & 0.033 & 0.060 & & & & & & & \\
\hline 4 & Loganberry-Marlboro & 0.101 & 0.085 & 0.071 & 0.174 & & & & & & \\
\hline 5 & Preussen-Superlative & 0.065 & 0.075 & 0.047 & 0.119 & 0.284 & & & & & \\
\hline 6 & British & 0.033 & 0.045 & 0.026 & 0.079 & 0.101 & 0.198 & & & & \\
\hline 7 & Fall Fruiting & 0.066 & 0.055 & 0.011 & 0.094 & 0.065 & 0.089 & 0.240 & & & \\
\hline 8 & Newburgh-Sunrise & 0.104 & 0.029 & 0.010 & 0.065 & 0.047 & 0.077 & 0.143 & 0.234 & & \\
\hline 9 & Malling Exploit- & & & & & & & & & & \\
\hline & Malling Promise & 0.077 & 0.047 & 0.048 & 0.127 & 0.074 & 0.134 & 0.148 & 0.181 & 0.255 & \\
\hline 10 & $\begin{array}{l}\text { Lloyd George } x \\
\text { Preussen }\end{array}$ & 0.047 & 0.077 & 0.027 & 0.126 & 0.196 & 0.146 & 0.168 & 0.187 & 0.218 & 0.306 \\
\hline
\end{tabular}

${ }^{z}$ All possible matings, self-matings excluded. Varieties composing cluster groups are listed in Table 4.

group, includes 13 varieties that originated in diverse locations. Seven of the 13 varieties have either 'Malling Exploit' or its sib, 'Malling Promise', in their pedigrees. 'Kirzhatch' is $50 \%$ 'Malling Promise' and 50\% 'Carnival'. 'Dalnaya', 'Nootka', and 'Tulameen' all have $>25 \%$ 'Carnival' and form a subgroup within this cluster. 'Nootka', 'Meeker', and 'Wawi' all have 'Willamette' as one parent.

Cluster group 10, the 'Lloyd George' $\times$ 'Preussen' group, has European and Russian varieties derived from one of five clones from the cross of 'Lloyd George' $\times$ 'Preussen' or its reciprocal. Nine of the 11 varieties have No. 185, 'Paul Camenzind', 'Klon II Munchenberg', 'Rubin', or 'Schoenmann' in their pedigrees. 'Spica' and 'Zeva II' are both 'Preussen' derivatives crossed with 'Willamette' and are included in this group based on their relationship to 'Sirius' and 'Zeva I'. This group has a high CR with group 5, the 'Preussen-Superlative' group. 'Norna' is another variety from the cross of 'Preussen' $\times$ 'Lloyd George' but is in group 5 with varieties with a higher proportion of 'Superlative', rather than with those in group 10 .

Levels of inbreeding. Inbreeding coefficients of varieties ranged from 0.0 for 42 varieties to 0.625 for 'Himbo Star', with 12 varieties having an inbreeding coefficient of 0.5 (Table 4). The inbreeding coefficients are subject to the accuracy of the pedigree records. If more complete records were available, some of the founding clones would be identified as being related. Because these records are lacking, the founding clones are assumed to be unrelated, and, as a result, the estimate of the inbreeding coefficient may be too low. However, open-pollinated seedlings were assumed to be the result of self pollination. In the case where open-pollinated seedlings were actually hybrids, this assumption may overestimate the inbreeding coefficient.

The British and Pacific Northwest varieties in cluster group 6 of the genetic relatedness analysis have the longest breeding history, but this group has one of the lowest inbreeding coefficients (0.076). This result indicates that inbreeding can be minimized with attention to the mating system.

Even where the inbreeding coefficients are, on average, high, it does not necessarily mean that there is a high degree of homozygosity. Shaw (1991) commented on the high inbreeding coefficients calculated by Sjulin and Dale (1987) for strawberry. He thought that their estimates were high because 1) breeding populations were maintained with a larger genetic base, and 2) in California, there was no correlation between inbreeding coefficients and the performance variables for several breeding lines.
Also, in red raspberry the heterozygote appears to have a selective advantage (Jennings, 1967, 1972).

Maintaining and increasing genetic diversity. Four strategies can be and are being adopted by red raspberry breeders throughout the world to maintain or increase genetic diversity. These are a) increase the number of parents per generation, combined with a controlled system of mating; b) introduce partly or completely unrelated germplasm from improved sources of red raspberry; c) introduce germplasm from wild $R$. idaeus subsp. idaeus or stigosus; and d) introduce unimproved germplasm from other species of the subgenus idaeobatus.

Increasing the number of parents per generation reduces the rate of inbreeding $(\mathrm{Li}, 1955)$ and minimizes the loss of genetic diversity by random genetic drift (Allard, 1960). Random genetic drift will increase the actual level of inbreeding above that estimated in Table 4 (Hartl, 1980). When a controlled system of mating is practiced, in which the least-related parents of each generation are intercrossed, the rate of inbreeding will be half that of a random-mating population ( $\mathrm{Li}, 1955)$.

Genetic diversity can be increased by introduction of partially or unrelated $R$. idaeus improved germplasm. The pedigree analysis indicates that genetic diversity in European and North American varieties can be increased if the Russian varieties derived from 'Novost Kuzmina' are crossed with them. Also, the crosses between European and North American varieties will continue to increase the genetic diversity within the resulting varieties.

Genetic diversity can also be increased by using wild germplasm from $R$. idaeus subsp. idaeus and strigosus. Although subsp. idaeus has been studied by several workers (Haskell, 1960; Jennings, 1964; Keep, 1972; Misic and Tesovic, 1973; Rousi, 1965; Rozanova, 1939), very few traits were considered to be useful in raspberry breeding. In subsp. strigosus, however, useful characters have been identified from studies of a relatively small germplasm base (Daubeny, 1972, 1980; Dorsey, 1921; Van Adrichem, 1972; Vrain and Daubeny, 1986). Within this subspecies, hardiness, large fruit size, aphid resistance, and resistance to the nematode Pratylenchus penetrans (Cobb) Fil. $\&$ S. Stek. and cane diseases (H.A. Daubeny, personal communication) have been identified.

The subgenus idaeobatus Focke has more than 200 species that can be used to increase the genetic diversity within red raspberry. Many have been used as donors to improve breeding, mostly for resistance to pests and diseases (Jennings, 1988), although few have so far contributed to named varieties. Rubus 
Table 4. Origin and inbreeding coefficients $(F)$ of raspberry cultivars grouped by $C R$ cluster analysis.

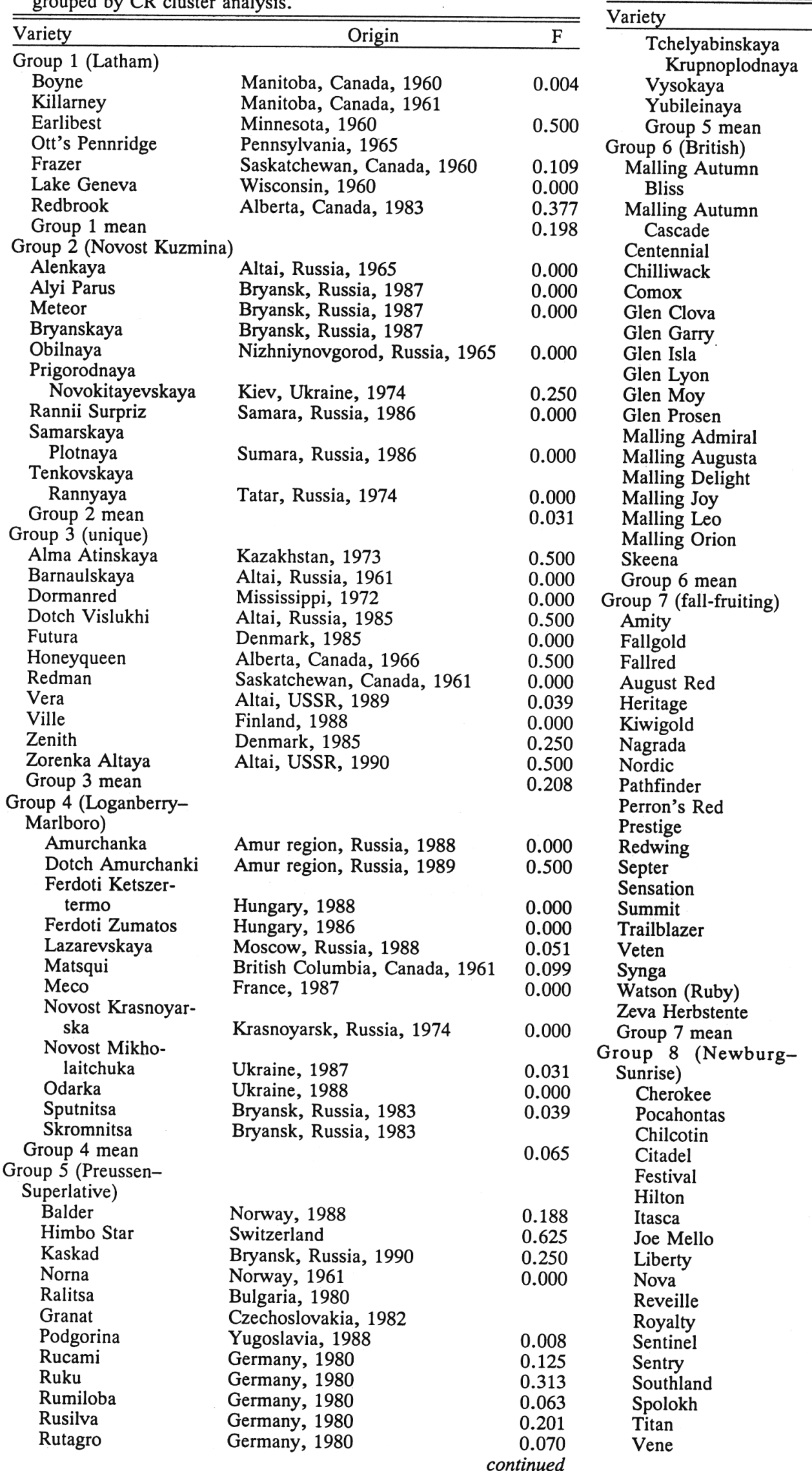

Table 4. continued.

\begin{tabular}{lc}
\multicolumn{1}{c}{ Origin } & F \\
\hline & \\
Tchelyabinsk, Russia, 1965 & 0.500 \\
Yekaterinburg, Russia, 1979 & 0.000 \\
Tatar, USSR, 1974 & 0.00 \\
& 0.180
\end{tabular}

England, 1983

England, 1990

0.161

Washington, 1989

0.012

British Columbia, Canada, $1986 \quad 0.015$

British Columbia, Canada, $1986 \quad 0.133$

Scotland, 1969 , 0.047

Scotland, $1989 \quad 0.100$

Scotland, 1974

Scotland, $1989 \quad 0.152$

Scotland, $1981 \quad 0.172$

Scotland, $1981 \quad 0.106$

England, $1971 \quad 0.000$

England, $1989 \quad 0.139$

England, $1973 \quad 0.129$

England, $1980 \quad 0.115$

England, $1976 \quad 0.000$

England, $1971 \quad 0.016$

British Columbia, Canada, $1977 \quad 0.000$

0.076

Oregon, 1984

0.081

New Hampshire, $1967 \quad 0.117$

New Hampshire, $1964 \quad 0.070$

New Hampshire, 1973

New York, 1969

New Zealand, 1988

Nizhniynovgord, Russia, $1973 \quad 0.250$

Minnesota, 1987 0.063

Wyoming, $1976 \quad 0.000$

Quebec, Canada, $1987 \quad 0.074$

New Hampshire, $1979 \quad 0.250$

Minnesota, $1986 \quad 0.177$

Maryland, $1966 \quad 0.125$

Illinois, $1974 \quad 0.500$

Oregon, $1989 \quad 0.236$

Wyoming, $1976 \quad 0.000$

Norway, $1961 \quad 0.000$

Norway, 1961

New York, $1988 \quad 0.107$

Switzerland, $1963 \quad 0.500$

0.156

Virginia, 1972

Virginia, 1972

British Columbia, Canada, $1977 \quad 0.000$

Maryland, $1966 \quad 0.086$

Ontario, Canada, $1972 \quad 0.125$

New York, $1965 \quad 0.000$

Minnesota, $1965 \quad 0.500$

California $\quad 0.000$

Iowa, $1976 \quad 0.000$

Nova Scotia, Canada, $1981 \quad 0.075$

Maryland, $1966 \quad 0.094$

New York, $1982 \quad 0.141$

Maryland, $1966 \quad 0.000$

Maryland, $1966 \quad 0.000$

North Carolina, $1968 \quad 0.094$

Moscow, Russia, $1988 \quad 0.250$

New York, $1986 \quad 0.156$

Norway, $1987 \quad 0.000$

continued 
Table 4. continued.

\begin{tabular}{|c|c|c|}
\hline Variety & Origin & $\mathrm{F}$ \\
\hline Group 8 mean & & 0.09 \\
\hline \multirow{2}{*}{\multicolumn{3}{|c|}{$\begin{array}{l}\text { Group } 9 \text { (Malling Exploit- } \\
\text { Malling Promise) }\end{array}$}} \\
\hline & & \\
\hline Agonquin & British Columbia, Canada, 1990 & 0.03 \\
\hline Anita & Mexico, 1989 & 0.50 \\
\hline Gina & Mexico, 1989 & \\
\hline Avon & Nova Scotia, 1967 & 0.00 \\
\hline Dalnaya & Moscow, Russia, 1987 & 0.0 \\
\hline Fairview & Oregon, 1961 & 0.0 \\
\hline Haida & British Columbia, 1973 & 0.00 \\
\hline Himbo Queen & Switzerland & 0.0 \\
\hline Jochems Roem & Netherlands, 1966 & 0.5 \\
\hline Kirzhatch & Moscow, Russia, 1985 & 0.0 \\
\hline Meeker & Washington, 1967 & 0.0 \\
\hline Nootka & British Columbia, Canada, 1977 & 0.0 \\
\hline Tulameen & British Columbia, 1990 & 0.0 \\
\hline Wawi & France, 1987 & 0.1 \\
\hline \multirow{2}{*}{\multicolumn{3}{|c|}{$\begin{array}{l}\text { Group } 9 \text { mean } \\
\text { Group } 10 \text { (Lloyd }\end{array}$}} \\
\hline & & \\
\hline \multicolumn{3}{|l|}{ George $x$ Preussen) } \\
\hline Ljulin & Bulgaria, 1982 & 0.0 \\
\hline Krupna Dvoroda & Yugoslavia, 1975 & 0.0 \\
\hline Gradina & Yugoslavia, 1975 & \\
\hline Esenna Pozlata & Bulgaria, 1985 & 0.2 \\
\hline Geloy & Germany, 1963 & 0.0 \\
\hline Gevalo & Germany, 1963 & 0.0 \\
\hline Tragilo & Germany, 1963 & \\
\hline Promiloy & Germany, 1963 & 0.0 \\
\hline Shopska Alena & Bulgaria, 1985 & 0.0 \\
\hline Sirius & Netherlands, 1973 & 0.12 \\
\hline Spica & Netherlands, 1973 & 0.0 \\
\hline Zeva I & Switzerland, 1960 & 0.12 \\
\hline Zeva II & Switzerland, 1960 & 0.0 \\
\hline Group 10 mean & & 0.0 \\
\hline Overall Mean & & 0.1 \\
\hline
\end{tabular}

${ }^{z}$ Cluster analysis (Ward's hierarchical method) based on CR for al possible combinations of matings, full-sib matings excluded.

occidentalis has been used as a donor of fruit firmness and resistance to all strains of Amphorophora idaei Börn (Keep and Knight, 1968). However, to date, germplasm from only 'Cumberland' has been used in developing red raspberry varieties, despite the species being completely interfertile with $R$. idaeus. Rubus parvifolius and $R$. kunzieanus have been used to develop varieties for warm climates (Jennings, 1988), $R$. cockbunteanus for late-season and many-flowered laterals (Knight, et al., 1989), $R$. spectabilis Pursh. for earliness (Knight, 1991), and R. arcticus L. for flavor (Hiirsalmi, 1989). Many species, both within subgenus idaeobatus and in other subgenera, have been reported to carry other traits, including resistance to all major fungal diseases and insect pests (Keep, 1989). However, the $F_{1}$ hybrids of these species with $R$. idaeus are often partially or completely sterile, which necessitates several generations of backcrossing to regain fertility (Keep and Knight, 1968).

To increase genetic diversity, a well-planned approach through recurrent selection is needed. This topic was discussed in Sjulin and Dale (1987) in relation to increased genetic diversity in the strawberry. Their discussion concluded that a recurrent selection system would require more generations of selection than a backcross system of mating but would allow for continued improvement of multiple traits for many generations.

Any of the four strategies outlined here can be used to maintain or increase genetic diversity within red raspberry. The first

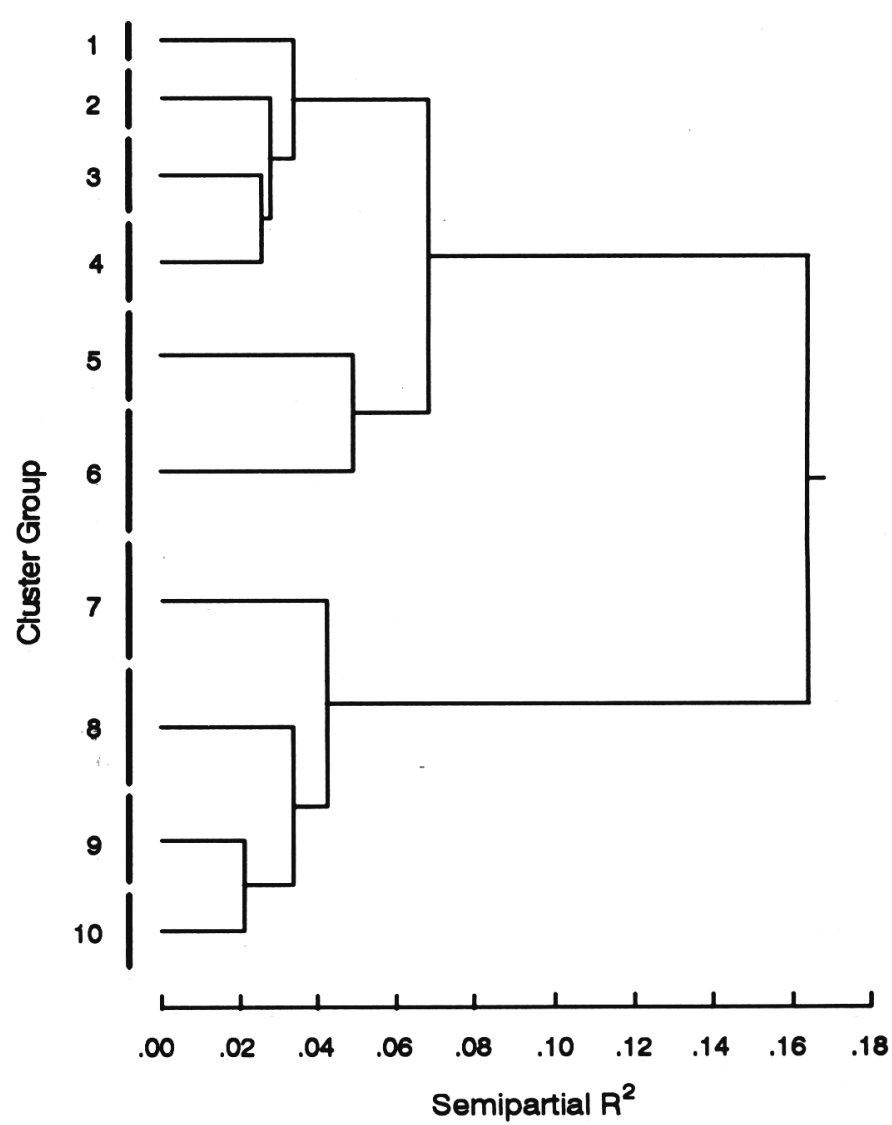

Fig. 2. Cluster dendogram of the world's red raspberry varieties based on CR, using Ward's hierarchical method. Varieties composing cluster groups are listed in Table 4 . Vertical bars indicate relative numbers of varieties in each cluster group.

two strategies will maintain the genetic diversity in the short term, but the latter two are required to maintain long-term improvement in red raspberries.

\section{Literature Cited}

Allard, R.W. 1960. Principles of plant breeding. Wiley, New York.

Barr, A.J. 1983. The inbreed procedure, p. 121-130. In: S.P. Joyner (ed.). SUGI supplemental library user's guide. 1983 ed. SAS Institute, Cary, N.C.

Brooks, R.M. and H.P. Olmo. 1971. Register of new fruit and nut varieties list 26. HortScience 6:439-442.

Brooks, R.M. and H.P. Olmo. 1972a. Register of new fruit and nut varieties. 2nd ed. Univ. of California Press, Berkeley.

Brooks, R.M. and H.P. Olmo. 1972b. Register of new fruit and nut varieties list 27. HortScience 7:455-460.

Brooks, R.M. and H.P. Olmo. 1973. Register of new fruit and nut varieties list 28. HortScience 8:378-383.

Brooks, R.M. and H.P. Olmo. 1974. Register of new fruit and nut varieties list 29. HortScience 9:437-441.

Brooks, R.M. and H.P. Olmo. 1975. Register of new fruit and nut varieties list 30. HortScience 10:471-478.

Brooks, R.M. and H.P. Olmo. 1978. Register of new fruit and nut varieties list 31. HortScience 13:522-532.

Brooks, R.M. and H.P. Olmo. 1982. Register of new fruit and nut varieties list 31. HortScience 17:17-23.

Brooks, R.M. and H.P. Olmo. 1983. Register of new fruit and nut varieties list 33. HortScience 18:155-161. 
Brooks, R.M. and H.P. Olmo. 1984. Register of new fruit and nut varieties list 34. HortScience 19:359-363.

Daubeny, H.A. 1972. Screening red raspberry varieties and selections for immunity to Amphorophora agathonica Hottes. HortScience 7:265266.

Daubeny, H.A. 1980. Red raspberry variety development in British Columbia with special reference to pest response and germplasm exploitation. Acta Hort. 112:59-67.

Daubeny, H.A. 1982. Expansion of genetic resources available to red raspberry breeding programs. Proc. 21st Intl. Hort. Congr. 1:1501.55 .

Dorsey, M.J. 1921. Hardiness from the horticultural point of view. Proc. Amer. Soc. Hort. Sci. 18:173-178.

Fejer, S.O. 1977. Inheritance of yield, yield components and fallfruiting habit in red raspberry diallel crosses. Can. J. Genet. Cytol. 19:1-13

Fejer, S.O. and L.P.S. Spangelo. 1974. Three generations of inbreeding and $\mathrm{S}_{2}$ factorial test crosses in red raspberry variety. Can. J. Genet. Cytol. 16:419-432.

Hancock, J.F. and J.H. Siefker. 1982. Levels of inbreeding in highbush blueberry varieties. HortScience 17:363-366.

Hartl, D.L. 1980. Principles of population genetics. Sinauer, Sunderland, Mass.

Haskell, G. 1960. The raspberry wild in Britain. Watsonia 4:238-255

Hedrick, U.P. (ed.). 1925. The small fruits of New York. New York State Agr. Expt. Sta. Rpt. 1925, part II.

Hiirsalmi, H.M. 1989. Breeding of Rubus species in Finland. Acta Hort. 262:75-81.

Jennings, D.L. 1964. Some evidence of population differentiation in Rubus idaeus L. New Phytol. 63:153-157,

Jennings, D.L. 1967. Balanced lethals and polymorphism in Rubus idaeus. Heredity 22:465-479.

Jennings, D.L. 1972. Aberrant segregation of a gene in the raspberry and its association with effects on seed development. Heredity 29:8390.

Jennings, D.L. 1988. Raspberries and blackberries: Their breeding, diseases and growth. Academic Press, London.

Jennings, D.L., H.A. Daubeny, and J.N. Moore. 1991. Blackberry and raspberry (Rubus), p. 331-389. In: J.N. Moore and J. Ballington, Jr. (ed.). Genetic resources of temperature fruit and nut crops. vol. 1 I.S.H.S., Wageningen, The Netherlands.

Keep, E. 1968. Incompatibility in Rubus with special reference to $R$. idaeus L. Can. J. Genet. Cytol. 10:253-262.
Keep, E. 1972. Variability in the wild raspberry. New Phytol. 71:915924.

Keep, E. 1989. Breeding red raspberry for resistance to diseases and pests. Plant Breeding Revs. 6:245-321.

Keep, E. and R.L. Knight. 1968. Use of black raspberry (Rubus occidentalis L.) and other Rubus species in breeding red raspberries. Rpt. East Malling Res. Sta. for 1967. p. 105-107.

Knight, V.H., D.L. Jennings, and R.J. McNicol. 1989. Progress in the UK raspberry breeding programme. Acta Hort. 262:93-103.

Knight, V.H. 1991. Use of the salmonberry Rubus spectubilis Pursh., in red rasberry breeding. J. Hort. Sci. 66:575-581.

Li, C.C. 1955. Population genetics. Univ. of Chicago Press, Chicago.

Lyrene, P.M. 1981. Recurrent selection in breeding rabbiteye blueberries (Vaccinium ashei Reade). Euphytica 30:505-511.

Misic, P. and Z.V. Tesovic. 1973. The native red raspberry, Rubus idaeus in western Serbia and eastern Montenegro. Jugoslov. Vocarstvo 7:1-9.

Overcash, J.P. 1972. Dormanred raspberry: A new variety for Mississippi. Bul. Mississippi Sta. Univ. 793.

Oydvin, J. 1970. Important parent varieties in raspberry breeding. Publ. Statens Forsoksgard Njos. p. 42.

Rousi, A. 1965. Variation among populations of Rubus idaeus in Finland. Ann. Agr. Fenniae. 41:49-58.

Rozanova, M.A. 1939. Evolution of cultivated raspberry. C.R. (Dokl.) Acad. Sci. URSS 18:677-680.

Scorza, R., S.A. Mehlenbacher, and G.W. Lightner. 1985. Inbreeding and coancestry of freestone peach varieties of the eastern United States and implications for peach germplasm improvement. J. Amer. Soc. Hort. Sci. 110:547-552.

Shaw, D.V. 1991. Recent advances in the genetics of strawberry, $p$. 76-83. In: A. Dale and J.J. Luby (eds.). The strawberry into the 21st century. Timber Press, Portland, Ore.

Sjulin, T.M. and A. Dale. 1987. Genetic diversity of North American strawberry varieties. J. Amer. Soc. Hort. Sci. 112:375-385.

Van Adrichem, M.C.J. 1972. Variation among British Columbia and northern Alberta populations of raspberries, Rubus idaeus subspp. strigosus Michx. Can. J. Plant Sci. 52:1067-1072.

Vrain, T.C. and H.A. Daubeny. 1986. Relative resistance of red raspberry and related genotypes to the root lesion nematode. HortScience 21:1435-1437.

Ward, J.H. 1963. Hierarchial grouping to optimise an objective function. J. Amer. Stat. Assn. 58:236-244.

Wright, S. 1922. Coefficients of inbreeding and relationship. Amer. Naturalist $56: 330-338$. 